\title{
Knowledge Innovation of Great Tradition of Chinese Literary Anthropology*
}

\author{
HU Jian-sheng, YUE Jian-feng \\ Shanghai Jiao Tong University, Shanghai, China
}

\begin{abstract}
It is very innovative significance that Chinese Literary Anthropology invents the Great Tradition in the new century and puts forward series of theoretical propositions and academic points based on it. The new Great Tradition transforms the opposition between the Great and Little Tradition of American anthropology, and makes the new concepts gain the legitimacy of the cultural values transferred from the old terms. It dates the second coded significance of the written culture from the material narrative and the image narrative of the oral tradition, and highlights the generative and primary of the symbolic significance. It also questions the authenticity of the written representation, endows the truth and credibility to the material and image representation, and manifests the imaginative and expression of the early human culture. Though its theoretical innovation inverts the binary opposition structure, and it wants to jump out of knowledge limits of dual structure such as structure and destruction, objective and subjective, material and spiritual.
\end{abstract}

Keywords: Chinese Literary Anthropology, Ye Shuxian, Great Tradition, Little Tradition, theoretical innovation

In the year of 1956, American anthropologist Robert Redfield came up with his renowned concept "Great Tradition" and "Little Tradition" in his book of Peasant Society and Culture: An Anthropological Approach to Civilization. By Great Tradition, he refers to the writing traditions of philosophers, theologians, literature writers, that is to say, a tradition that intentionally to be inherited and learnt at schools or temples, while Little Tradition referring to the folk inheriting tradition that transmitted orally. ${ }^{1}$ In the "Great Tradition" and "Little Tradition" of Chinese culture, Ye Shuxian re-creates and innovates the implied meaning of the Great Tradition and Little Tradition, "I think there is an necessity to reverse the definition of Redfield, and we should name the Chinese character coding culture tradition as Little Tradition while the tradition of pre-character era as Great Tradition". ${ }^{2}$ He transposes "Little Tradition" and "Great Tradition”, and totally reverses the terminology and significance meaning. This dualism seems to be plain, but inside it there is plenty possibilities and innovation, which has ushered a new direction and vista for the innovation of academic knowledge innovation. The thought

\footnotetext{
* Acknowledgements: This paper is sponsored by the Special Fund Project of Interdisciplinary Research between Arts and Science of Shanghai Jiao Tong University in China: the phased objectives of "Social Space and the Cultural Representation of Confucian in Pre-Qin Age” (13JCY12).

HU Jian-sheng is an Associate Professor at School of Humanities, Shanghai Jiao Tong University. His research area is Chinese Literary Anthropology, Cross-culture research, Chinese classical culture and literature.

YUE Jian-feng is a Ph.D. Candidate who majors in British and American literature in Shanghai Jiao Tong University.

${ }^{1}$ Robert Redfield, Peasant Society and Culture: an Anthropological Approach to Civilization, Chicago: University of Chicago Press, 1956, p. 70.

${ }^{2}$ Ye Shuxian (葉舒憲), 中國文化的大傳統和小傳統 (The Great Tradition and Little Tradition of Chinese Culture), Dang Jian 黨建, 2007(2), pp. 49-51.
} 
pattern and value system of Great Tradition can provide a possibility of switching academic perspectives at the fields of traditional Chinese literature, history and philosophy and is endowed with a great sense of culture innovation.

This article mainly focuses on a rational analysis on the innovative significance and pattern of Ye Shuxian's Great traditional knowledge pattern, unveiling the legally transmitting of Great Tradition and its principles and cultural values, prompting the contribution of Great Tradition upon academic innovation. Meanwhile, it will also analyze the rigid pattern and over-simplification in the process of the academic innovation of Great Tradition theory and further advises on its multi-polarities.

\section{Part 1 The Transferring of Cultural Values: Pre-historical “Little Tradition” to Cultural “Great Tradition"}

When distinguish the terminology "Great Tradition" and "Little Tradition", we think the dual concept is developing from the following concepts "higher culture" and "lower culture”, "folk culture” and "classical culture”, "popular culture” and "academic culture”, "sacred culture” and "mundane culture”. 3 From all there dualistic academic expressions, we can clearly conclude that: according to the anthropologists, cultural "great tradition”, "higher education”, "classical culture”, "academic culture” and "scared culture” belongs to the same cultural level, which symbolize the upper-class, higher-end, orthodox and legitimacy, while cultural "Little Tradition" and "lower culture", "folk culture", "popular culture" and "mundane culture” belong to the lower-class, unorthodox and illegitimacy, namely, the "Great Tradition" terminologies are welcomed by the ruling class, thus the occupation of expression has divided the ruling class and the ruled class. The cultural "Little Tradition" represents the folk cultural tradition, which is inherited from generation to generation in an oral way and is restricted to villagers whole educated level is relatively low. Thus it is the negative valued cultural tradition that belongs to the ruled class. So we can see that from the perspective of anthropologists, the dual expression of Great Tradition and Little Tradition, written transmission and oral transmission can be symbols to distinguish the civilized and the barbarian, the advanced and the remote, the legitimate and the illegitimate, from there the contradicted relations between social classes can be represented.

The new theory of Great Tradition is an innovation of anthropologists upon the Great Tradition and Little Tradition, which on one hand fully borrows from the dual terminologies of anthropologists, and boldly reversed the cultural value and cultural meanings of the terms; on the other hand the new theory of Great Tradition of culture naturally gains the legitimate transferring from the terminological aspect and with Ye's recreation, the cultural significance and cultural value are more refined and innovative, with a much more significant influence. Ye refers the pre-historical folk culture as Great Tradition, which reflecting the originality of coding in pre-historical cultural tradition and transferring the legitimate value of anthropological "Great Tradition" to folk cultural tradition, making the once "debased", "folk", "popular" and "mundane” culture regaining a sacred and absolute coding significance and cultural value, and reverse into energetic, valuable and legitimate cultural expression. Meanwhile, Ye debase the once orthodox written culture into "Little Tradition" and thus definitions like "higher culture”, "academic culture”, "sacred culture” and "classical culture” are accordingly reversed, losing their cultural legitimate value.

Ye Shuxian's innovative creation on the anthropological culture is a groundbreaking understanding and

\footnotetext{
${ }^{3}$ Robert Redfield, Peasant Society and Culture: an Anthropological Approach to Civilization, Chicago: University of Chicago Press, 1956, p. 70.
} 
transformation on the primitiveness and generating of the pre-historical symbols, and offering an efficient and significant innovation on the real value and appearance of early Chinese culture and history.

\section{Part 2 Primitiveness of Meaning Generating: From Written Code to Oral Material Image}

In the traditional system of "Great Tradition" and "Little Tradition” of anthropologists, the written Great Tradition was placed on the center of meaning generating. Thus, making the written Great Tradition the inevitable cultural tradition and even give out a misunderstanding that written culture can symbolize all the cultural construction and whereas the oral culture was discriminated and outlawed, even can be dismissed. The culture and pictures inherited from the era of oral culture played the sacred and authorized role of the supplement of written system. Especially when anthologists link Great Tradition with adjectives such as higher, scared and civilized, which even more heightened the authority and reality of written system, and equalize the Little Tradition as mundane, barbarian and lower-end, thus the originality, primitiveness and intriguing of Little Tradition has long been ignored. The whole theoretical system impresses one that history is rooted in written tradition and the significance of history must be raced back in written texts.

The recreation and reinvention of the new theory on anthropological Great Tradition and Little Tradition reveals the purposefully covering of historical fact and regains the cultural achievement on historical fact and cultural fact. Ye Shuxian's substitution with written tradition to oral tradition is of great cultural significance in the originality and primitiveness of the re-inventing and stressing of cultural meaning. Firstly, the new theory of Great Tradition enhances the language expression to the cultural material and picture expression, and the significance of cultural code turns from written characters to primitive mythological meaning, and hence define the material expression and picture expression as the first level code of human's history and culture, which has lasting effects on further culture and history, and also is the prototype of the written code. So various archaeological relics were left in an ignorant state, and further turned into the original text and imaginative cultural root, which can be further traced as the primitive state of all civilization and cultural significance. Secondly, the new theory of Great Tradition turns written code from the first level to the second level, and has undergone the swift from center to derivative and secondary state. Meanwhile, the oral code was transformed from the second level to the first. Thirdly, the redefinition of Great Tradition and Little Tradition certifies that the two layers of code meaning are not imaginatively generated by the written system. All the confidence and arrogance of the words, which is expressed by "the book is definitely believed", had been largely doubted, which means the meaning of writing code must be gained from material expression and prototype significance. So the new theory of Great Tradition has re-ranked the Great Tradition and Little Tradition, which certifies the rank of cultural code and symbolization. At the new theory of Great Tradition, the unearthed antiques and pictures turn into the first-level cultural code and only if one understand the hidden code behind them can one illustrate the second-layer code of primitive significance.

Traditional Chinese culture has been endowed with thousands years of notes and commentaries, which had been legitimate and authorized at earlier stages. But if we can be certain of the first level of code at the Great Tradition and combined with early material culture and picture narration, the second-level written interpreting system can be misread and misunderstood, which can only be clarified at Great Culture Tradition. Meanwhile, some unclear or contradicted part of classical interpretation can be reasonably explained only in a situation of primitive first-level codes. The Cultural Great Tradition, as a form of cultural innovation, has provided 
numerous possibilities for meaning generating. Due to this, Ye Shuxian came up with the four-layer academic evidence formula, especially the forth layer, which has unveiled the illustrative function of the cultural gene and code in traditional Chinese culture, and a expressive significance in the prototype culture.

\section{Part 3 The Possibility of Cultural Imagination: The Reality of Characteristic Expression and Picture Expression}

The re-invention of the Great Tradition and Little Tradition of anthropology directly challenged the issue of reality and fictional at the cultural expression and transmitting medium. In the anthropological system of Little Tradition and Great Tradition, the written form is by no doubt the most realistic historical expression, and all the written form can be the evidence of the historians and literacy authors, and all historical expression deviating away the written evidence has turned into illegitimate fictional history. Thus we can learn that the historical view of anthropologists are based on written history and they think only written history is reliable and truthful and definitely trustworthy, that is to say, they establish the authenticity of history on the base of the second-level cultural code and has ignored the inheritance and willingness of written or oral form.

The new theory of Great Tradition has unveiled the reality and existence of culture and history, namely, the starting point of history is not the second-level code, but the primitive first-level code. Early human history usually explores man's perception and cultural imagination in a material narrative and picture narrative. So we can conclude that the early unearthed materials are no longer inaudible subjective matter but a material expression or culture. The literature anthropology aims at real voice of history in order to restore the cultural reflection and perception of early human beings. All images in early human stages are substitutive depiction of realistic culture or relics of picture expression, which is the re-abstracted existing form of material culture, and it has the same cultural imagination and cultural significance. In the switch of perspective of the new theory of Great Tradition, the material culture and mythological image has gained the perception and reality, which could ushered the new key and path of the origin of the historical civilization. Ye Shuxian paid special attention to the new unearthed material all over the world, and the materials in museums and libraries, from which he can utilize all these images and subjects to prove the cultural belief and mythological values, and thus highlight the restoring way and its cognitive effect the principle of "confronting the truth" phenomenology had always stressed.

The new theory of Great Tradition has endowed the existing and reality of cultural imagination and perception. Ye Shuxian repeatedly stressed that the concrete objects are better evidence than written languages, and he believes that we should put the material narration, picture narration as the more important evidence than the first, the second and the third evidence, then we can gain an illustrative effect of "cubist interpretation of history", which can further result in a new understanding of "cultural integration". 4 We can conclude that whether evidence effect or reality of cultural imagination, the new theory of Great Tradition believed that the authenticity and credulity of material and picture expressions are all belong to a primitive category, whose significance had much surpassed the written narration.

\section{Part 4 The Contradiction of Knowledge Innovation: From Structuralism-Oriented to Mythologies-Oriented}

Recently, Ye has published a series of thesis concerning “jade”, respectively “The Evolution of Godness”,

${ }^{4}$ Ye Shuxian, 文學人類學教程 (Literary Anthropology), Beijing: 中國社會科學出版社, 2010, p. 376. 
"Confucian Mythology" and "Descendants of Royal Families", which have rose wide attention in academic circle. As to theoretical research, he has come up with four-layers of evidence and five-layers of narrative mode, as well as N-polar cultural coding theory. In the origin of pre-historical civilization, he creatively constructed the "jade" tradition and the invention of pre-historical road of "jade and stone". Thus we can conclude that the great energy and contribution of innovative theory of Great Tradition is of great cultural illustrative significance.

But we should also be aware that the new theory structure of Great Tradition is an innovation upon the anthropological conception of "Great Tradition" and "Little Tradition", and is established on the definitive basis of the binary contradiction of anthropologists. Ye Shuxian said "it's necessary to transpose Redfield's definition” and established the new contradicted relations of the new theories of Great Tradition. Actually, Ye borrowed this transposed way from Western deconstructionism and postmodernism, and it is quite different from the entanglement of modern conventional knowledge and structuralism methodology and has already regained the theoretical innovative effect via the substitution of binary definitions. The subjective significance of the academic innovative is very obvious, but we should also be attentive that the knowledge reproduction and theoretical construction is an intentional academic behavior, which has a sheer subjective constitution and knowledge willingness. Ye had been long devoted to the mythological theory and cultural interpretation, and he has a deep understanding of how Western modernity had un-charmed the rationality of cultural spirit, religious belief and mythological imagination. He has come up with the opinion that we should reply modern crisis directly with culture, and he concluded these strategies as black thunderstorm, Celtic resurrection, Goddess resurrection, Oriental Transformation and ecological transformation. ${ }^{5}$ Thus we could conclude that the most basic feature and constructing strategy of cultural root-seeking is a path from rational "un-charm" to cultural "re-charm", which aims at the recollection of man's mythological and sacred consciousness in early historical stage and restore man's spirituality and imagination of culture. Once we combine the knowledge productive strategy of the new theory of Great Tradition with the contradicting structure of cultural "re-charm", we can clearly know the cultural meaning of dual expressive structure and reversed moving. The transposed mode of cultural construction, with a cultural logic that being contradicted with modernity, has indeed gained a fierce theoretical effect. Also it has arose attention from academic circle and revealed numerous knowledge innovation and academic wisdom.

Since the knowledge innovation of Great Tradition is a pair of transposed knowledge, which has endowed with a great sense of self-willingness. The current Western academic transformation, for example, from structuralism to deconstructionism, from subjectivity to objectivity, from structure-centered theory to wisdom-centered theory, from materialism to theology, from the one end of dual contradiction to the other end, from one kind of cultural crisis to another kind of cultural crisis. The Western innovation of mechanical knowledge on the contradictory of the subjective and the objective has ignored the reliance and variety of dual contradictory. So we should not only be clear of that in the new theory of the Great Tradition, the contradiction between Great Tradition and Little Tradition is a contradiction between the major and the minor, the primitive and the derivative, and we should also aware that the material and picture expression in the Great Tradition theoretical system is one of the modes of cultural behaviors, and both are man's collective cultural value and

\footnotetext{
${ }^{5}$ Ye Shuxian, 現代性危機和文化噩根 (The Crisis of Modernity and Cultural Root-seeking), Jinan: 山東教育出版社, 2009, pp. 3-5.
} 
cultural practice concerning the judgment of interest. On one hand the cultural expression of Great Tradition has offered certain amount of foundation of cultural significance for Little Tradition, and Little Tradition has inherited the primitive cultural meaning of the Great Tradition. No matter the narrator of Great Tradition or Little Tradition, their cultural value structure and expressive willingness tendency, and the cultural situation in concrete context and the cultural phenomenon of narration. The meaning of cultural code in cultural expression might undergo coherent adjustment and updating. Thus the significance of cultural code is historical. The relationship from first-level code to the second-level code is never a mechanical and fixed cultural inherited relationship, but a sense of continuous production and reproduction.

In addition, no matter material narration, picture narration in the Great Tradition, or the narration in the written tradition, they are all organic unity of material and perception, subjective and objective, structure and function, which are all mechanical contradiction of structure towards function, and vise versa. When constructing local knowledge of China, we should transcend this kind of constructional and functional duality can we avoid the subjective and personal dual contradicted structure, can we find a path of cultural integration with Chinese characteristics and further to endow stricter and more concise connotation on the new theory of Great Tradition.

\section{References}

Robert Redfield. (1956). Peasant Society and Culture: an Anthropological Approach to Civilization. Chicago: University of Chicago Press.

Ye Shuxian. (2007). 中國文化的大傳統和小傳統 (The Great Tradition and Little Tradition of Chinese Culture). 黨建,, 2.

Ye Shuxian. (2010). 文學人類學教程 (Literary Anthropology). Beijing: 中國社會科學出版社.

Ye Shuxian. (2009). 現代性危機和文化尋根 (The Crisis of Modernity and Cultural Root-seeking). Jinan: 山東教育出版社. 